\title{
Level of contamination with mycobiota and contents of mycotoxins from the group of trichothecenes in grain of wheat, oats, barley, rye and triticale harvested in Poland in 2006- 2008
}

\author{
Kinga Stuper-Szablewska', Juliusz Perkowski ${ }^{1}$ \\ ${ }^{1}$ Department of Chemistry, University of Life Sciences, Poznan, Poland \\ Stuper-Szablewska K, Perkowski J. Level of contamination with mycobiota and contents of mycotoxins from the group of trichothecenes \\ in grain of wheat, oats, barley, rye and triticale harvested in Poland in 2006-2008. Ann Agric Environ Med. 2017; 24(1): 49-55. \\ doi: $10.5604 / 12321966.1230733$
}

\begin{abstract}
I Abstract
Introduction and Objective. The risk of cereal exposure to microbial contamination is high and possible at any time, starting from the period of plant vegetation, through harvest, up to the processing, storage and transport of the final product. Contents of mycotoxins in grain are inseparably connected with the presence of fungal biomass, the presence of which may indicate the occurrence of a fungus, and indirectly also products of its metabolism.

Materials and method. Analyses were conducted on 378 grain samples of wheat, triticale, barley, rye and oats collected from grain silos located at grain purchase stations and at mills in Poland in 2006, 2007 and 2008. The concentrations of ERG and mycotoxins from the group of trichothecenes, as well as CFU numbers were analysed.

Results. The tested cereals were characterised by similarly low concentrations of both the investigated fungal metabolites and the level of microscopic fungi. However, conducted statistical analyses showed significant variation between tested treatments. Oat and rye grain contained the highest amounts of ERG, total toxins and CFU. In turn, the lowest values of investigated parameters were found in grain of wheat and triticale.

Conclusions. Chemometric analyses, based on the results of chemical and microbiological tests, showed slight differences between contents of analysed metabolites between the years of the study, and do not confirm the observations on the significance of the effect of weather conditions on the development of mycobiota and production of mycotoxins; however, it does pertain to treatments showing no significant infestation. Highly significant correlations between contents of trichothecenes and ERG concentration (higher than in the case of the correlation of the total toxin concentrations/log cfu/g), indicate that the level of this metabolite is inseparably connected with mycotoxin contents in grain.
\end{abstract}

I Key words

CFU, ergosterol, trichothecenes, cereals

\section{INTRODUCTION}

Cereals are the oldest crops and their milling products are staple food not only for humans, but also animal feed. In view of the considerable amounts of cereal products consumed by humans it seems fully justified to require thorough quality control of raw materials and cereal products. The risk of their exposure to microbial contamination is high and possible at any time, starting from the period of plant vegetation, through harvest, up to the processing, storage and transport of the final product [1].

Microorganisms commonly found in cereal products include microscopic fungi, while cereal pathogens colonising kernels are responsible, e.g. for the deterioration of grain processability. However, the greatest risk is posed by mycotoxins produced by microscopic fungi. They are secondary metabolites exhibiting a strong toxic effect both towards humans and animals.

Address for correspondence: Kinga Stuper-Szablewska, Department of Chemistry, Poznan University of Life Sciences, Wojska Polskiego 75, 60-637 Poznan, Poland E-mail: kstuper@up.poznan.pl

Received: 27 July 2015; accepted: 23 October 2015; first published on January 2017
The contents of mycotoxins in grain are inseparably connected with the presence of fungal biomass, the presence of which may indicate the occurrence of a fungus, and indirectly also products of its metabolism [2]. Among primary metabolites, ergosterol (ERG), a specific fungal marker, needs to be particularly stressed. Thus, when determining the level of mycobiota in terms of ERG concentration, from the results the contamination of grain with mycotoxins may be inferred with high probability, or potentially even estimate their concentrations. This has been proved by numerous studies in which the correlation coefficient determined between the content of one of the most common toxins found in grain, i.e. deoxynivalenol (DON) [3], and that of ergosterol, is high [4]. The content of ERG is also correlated with the concentration of another highly frequent mycotoxin observed in cereal grain, i.e. ochratoxin $\mathrm{A}$, and with a number of colony forming units of microscopic fungi.

Within this, study analyses were conducted on the level of contamination both of the microscopic fungi and their mycotoxins in grain samples of five cereal species (wheat, oat, barley, rye and triticale) grown in north-western Poland in 2006-2008. 


\section{MATERIALS AND METHOD}

Grain samples of five cereal species (triticale, wheat, barley, rye, oat) were obtained in 2006-2008 from grain silos located at grain purchase stations and mills in Poland. A total of 378 samples of $5 \mathrm{~kg}$ each were collected in accordance with the ordinance: Sampling methods for selected food products to monitor levels of Fusarium toxins and criteria for analytical methods applied to assay contents of Fusarium toxins. The numbers of samples collected in individual years are given in Table 1.

Table 1. Numbers of samples of five cereal species harvested in the years 2006-2008 in south-western Poland

\begin{tabular}{lcccc}
\hline \multirow{2}{*}{\begin{tabular}{l} 
Year \\
\cline { 2 - 5 }
\end{tabular}} & \multicolumn{4}{c}{ No. of samples collected in a given year } \\
\hline Triticale & 2006 & 2007 & 2008 & Total \\
\hline Wheat & 19 & 27 & 19 & 65 \\
\hline Barley & 24 & 36 & 34 & 110 \\
\hline Rye & 31 & 17 & 19 & 60 \\
\hline Oat & 24 & 25 & 25 & 81 \\
\hline All cereals & 133 & 129 & 116 & 378 \\
\hline
\end{tabular}

Analysis of trichothecenes. Grain samples were analysed for the presence of trichothecenes according to Perkowski et al. (2011) [4]. Sub-samples (10 g) were extracted with acetonitrile/water (82:18) and cleaned-up on a charcoal column (Celite 545/charcoal Draco G/60/activated alumina neutral 4:3:4 (w/w/w). Trichothecenes of group A ( $\mathrm{H}-2$ toxin, T-2 toxin, T-2 tetraol) were analysed as TFAA derivatives. The amount of $100 \mu \mathrm{l}$ trifluoroacetic acid anhydride was added to the dried sample. After $20 \mathrm{~min}$., the reacting substance was evaporated to dryness under nitrogen. The residue was dissolved in $500 \mu \mathrm{l}$ of isooctane and $1 \mu \mathrm{l}$ was injected onto a gas chromatograph-mass spectrometer. Trichothecenes of group B (DON, NIV, 3-AcDON, 15-AcDON) were analysed as TMS (trimethylsilylsilyl ether) derivatives. To the dried extract, the volume of $100 \mu \mathrm{l}$ TMSI/TMCS (trimethylsilyl imidazole/trimethylchlorosilane, v/v 100/1) mixture was added. After $10 \mathrm{~min}$., $500 \mu \mathrm{l}$ of isooctane were added and the reaction was quenched with $1 \mathrm{ml}$ of water. The isooctane layer was used for the analysis, and $1 \mu \mathrm{l}$ of the sample was injected on a GC/MS system. The analyses were run on a gas chromatograph (Hewlett Packard GC 6890) hyphenated to a mass spectrometer (Hewlett Packard 5972 A, Waldbronn, Germany), using an HP-5MS $0.25 \mathrm{~mm} \times 30 \mathrm{~m}$ capillary column. The injection port temperature was $280^{\circ} \mathrm{C}$, transfer line temperature $-280^{\circ} \mathrm{C}$, and the analyses performed with programmed temperatures, separately for group A and B trichothecenes. Group A trichothecenes were analysed using the following programmed temperatures: initial $80^{\circ} \mathrm{C}$ held for $1 \mathrm{~min}$, from $80^{\circ} \mathrm{C}-280^{\circ} \mathrm{C}$ at $10^{\circ} \mathrm{C} / \mathrm{min}$, and the final temperature maintained for $4 \mathrm{~min}$. For group $\mathrm{B}$ trichothecenes, the initial temperature was $80^{\circ} \mathrm{C}$, held for $1 \mathrm{~min}$, from $80^{\circ} \mathrm{C}-200^{\circ} \mathrm{C}$ at $15^{\circ} \mathrm{C} / \mathrm{min}$, held for $6 \mathrm{~min}$, and from $200^{\circ} \mathrm{C}-280^{\circ} \mathrm{C}$ at $10^{\circ} \mathrm{C} / \mathrm{min}$, the final temperature being maintained for $3 \mathrm{~min}$. The helium flow rate was held constant at $0.7 \mathrm{ml} / \mathrm{min}$.

Quantitative analysis was performed in the single ion monitoring (SIM) mode using the following ions for the detection of scirpentriol (STO): 456 and 555; T-2 tetraol:
455 and 568; T-2 triol: 455 and 569 and 374; HT-2: 455 and 327; T-2: 327 and 401; deoxynivalenol (DON): 103 and 512; 3-acetyldeoxynivalenol (3-AcDON): 117 and 482; 15-acetyldeoxynivalenol 15-AcDON: 193 and 482; nivalenol (NIV): 191 and 600. Qualitative analysis was performed in the SCAN mode (100-700 amu). Recovery rates for the analysed toxins were as follows: STO $82 \pm 5.3 \%$; T-2 triol 79 $\pm 5.1 \%$; T-2 $86 \pm 3.8 \%$; T-2 tetraol $88 \pm 4.0 \%$; HT-2 91 $\pm 3.3 \%$; DON $84 \pm 3.8 \%$; 3 -AcDON $78 \pm 4.8 \%$; 15 -AcDON $74 \pm 2.2 \%$ and NIV $81 \pm 3.8 \%$. The limit of detection was $0.001 \mathrm{mg} / \mathrm{kg}$.

Chemical analysis of ergosterol. Ergosterol was determined by high-performance liquid chromatography (HPLC) [2]. Samples containing $100 \mathrm{mg}$ of ground grains were placed into $17-\mathrm{ml}$ culture tubes, suspended in $2 \mathrm{ml}$ of methanol, treated with $0.5 \mathrm{ml}$ of $2 \mathrm{M}$ aqueous sodium hydroxide, and tightly sealed. The culture tubes were then placed inside $250-\mathrm{ml}$ plastic bottles, tightly sealed and placed inside a microwave oven (Model AVM 401/1WH, Whirlpool, Sweden) operating at $2,450 \mathrm{MHz}$ and $900 \mathrm{~W}$ maximum output. Samples were irradiated $(370 \mathrm{~W})$ for $20 \mathrm{~s}$, and after about $5 \mathrm{~min}$ for an additional $20 \mathrm{~s}$. After $15 \mathrm{~min}$., the contents of theculture tubes were neutralized with $1 \mathrm{M}$ aqueous hydrochloric acid, $2 \mathrm{ml}$ $\mathrm{MeOH}$ were added and extraction with pentane $(3 \times 4 \mathrm{ml})$ carried out within the culture tubes. The combined pentane extracts were evaporated to dryness in a stream of nitrogen. Before analysis, the samples were dissolved in $4 \mathrm{ml}$ of $\mathrm{MeOH}$, filtered through $13-\mathrm{mm}$ syringe filters with a $0.5 \mathrm{~mm}$ pore diameter (Fluoropore Membrane Filters, Millipore, Ireland) and evaporated to dryness in $\mathrm{N}_{2}$ stream. The sample extract was dissolved in $1 \mathrm{ml}$ of $\mathrm{MeOH}$ and $50 \mu \mathrm{l}$ analysed by HPLC. Separation was performed on a $150 \times 3.9 \mathrm{~mm}$ Nova Pak C-18, 4-mm column and eluted with methanol/acetonitrile (90:10) at a flow rate of $0.6 \mathrm{ml} / \mathrm{min}$. Ergosterol was detected with a Waters 486 Tunable Absorbance Detector (Milford, MA, USA) set at $282 \mathrm{~nm}$. The presence of ERG was confirmed by a comparison of retention times and by co-injection of every $10^{\text {th }}$ sample with an ergosterol standard.

Plate flooding method with decimal dilutions. The count of microscopic fungi per $1 \mathrm{~g}$ of grain was assessed using a standard plate method in accordance with the procedure of the standard PN-ISO 21527-2: 2009. Microbiology of food and feeds. Horizontal method to determine counts of yeasts and moulds. Part 2: Method of counting colonies in products with water activity of max. 0.95 . The amount of $10 \mathrm{~g}$ comminuted material (in 3 replications) was suspended in $90 \mathrm{ml}$ of $0.1 \%$ peptone water. After $30 \mathrm{~min}$., samples were shaken for $2.5 \mathrm{~min}$. Next, from the prepared suspension decimal dilutions were prepared in $0.1 \%$ peptone water solution. For this purpose, $1 \mathrm{ml}$ of suspension was transferred with a sterile pipette from 3 prepared dilutions onto sterile Petri dishes (with 2 for each dilution). In the next stage, plates were flooded with agar medium containing Rose Bengal and chloramphenicol $(15 \mathrm{ml})$ at a temperature of $45^{\circ} \mathrm{C}$. Plates were incubated under aerobic conditions, placed flat in a heater at a temperature of $25 \pm 1^{\circ} \mathrm{C}$ for 5-7 days. After incubation, colonies were counted on selected plates (making it possible to obtain 15-150 colonies per plate), and based on the number of counted colonies, the number of colonyforming units (CFU) of microscopic fungi was calculated in $1 \mathrm{~g}$ of tested material (CFU/g). The result was a mean of 2 replications and expressed in log CFU/g [5]. 
Analysis of fungi occurrence in wheat. The composition of fungal species detected in wheat grain samples was analysed. The dilution method used was as follows: $1 \mathrm{~g}$ of ground grains was placed in $10 \mathrm{ml}$ of sterile distilled water and mixed with a magnetic stirrer for $2 \mathrm{~min}$. Next, $1 \mathrm{ml}$ of the suspension was transferred onto PDA (potato-dextrose agar) medium in Petri dishes and spread with a sterile glass stick on the medium surface. The Petri dishes were incubated at $25^{\circ} \mathrm{C}$ for 7 days. Growing mycelia were isolated on the PDA and SNA (synthetic nutrient-poor agar) media to identify fungal species. The identification was carried out on the basis of colony and spore morphology using keys [5].

Statistical analysis. Results were subjected to statistical analysis using the STATISTICA v 8.0 software. In order to compare the contents of individual metabolites in the samples, Tukey's multiple comparison procedure was applied. Moreover, values of Pearson's linear correlation coefficients were also determined at the following significance levels: $\alpha=0.05, \alpha=0,01$ and $\alpha=0,001\left({ }^{*},{ }^{* *},{ }^{* *}\right)$ between ERG and trichothecene concentrations and the number of CFU. In order to determine the effect of weather conditions on the level of wheat grain contamination with mycobiota and mycotoxins, multiple regression was applied and Pearson's linear correlation coefficient calculated at the level of significance $\alpha=0.05$ between analysed factors.

\section{RESULTS}

Analyses were conducted on 378 grain samples of wheat, triticale, barley, rye and oat in 2006, 2007 and 2008. In 2006, a total of 133 grain samples of 5 cereal species were tested. In that year, the contents of ERG and mycotoxins from the trichothecene group, as well as the number of CFU, were analysed (Tab. 2A). Among the investigated cereal species, oat grain was characterised by the highest concentrations of ERG, total toxins and CFU levels, which were recorded at $10.01 \mathrm{mg} /$ $\mathrm{kg}, 0,097 \mathrm{mg} / \mathrm{kg}$ and $3.40 \mathrm{log} \mathrm{cfu} / \mathrm{g}$. In contrast, in triticale grain, the lowest values of analysed metabolites and CFU were recorded, i.e. ERG concentration was $3.46 \mathrm{mg} / \mathrm{kg}$, total toxin concentration of $0,024 \mathrm{mg} / \mathrm{kg}$, while the content of microscopic fungi expressed in colony forming units was $1.53 \mathrm{log} \mathrm{cfu} / \mathrm{g}$. The other cereals contained by approx. 50\% less ERG than oats. In contrast, total toxin concentration in rye grain was slightly lower than in oat grain. Wheat and barley grain did not differ significantly in terms of their total trichothecene contents, which amounted to 0,038 and $0,036 \mathrm{mg} / \mathrm{kg}$, respectively. Wheat, barley and rye differed in terms of their CFU levels, which were $1.75,2.05$ and $2.36 \log \mathrm{cfu} / \mathrm{g}$, respectively. The content of microscopic fungi in wheat grain did not differ significantly from their contents in triticale.

Oat and rye grains varied the greatest in terms of their contents of analysed mycotoxins (Tab. 2B). In grain samples of these cereals, the following mycotoxins were detected at various concentrations: STO, T-2 Tetraol, T-2 Triol, DAS,

Table 2. Range and mean concentrations of total toxins, ergosterol and value of log cfu/g (A), mean concentrations of trichothecenes $A$ and $B$ (B) in grains of 5 cereal species harvested in 2006, and correlations between analysed traits (C)

\begin{tabular}{|c|c|c|c|c|c|c|c|}
\hline \multirow{2}{*}{$\begin{array}{l}\text { A } \\
\text { Cereal }\end{array}$} & \multirow{2}{*}{$\begin{array}{c}\text { No. of } \\
\text { samples }\end{array}$} & \multicolumn{2}{|c|}{ Mean ERG concentration ( $\mathrm{mg} / \mathrm{kg})$} & \multicolumn{2}{|c|}{ Mean total toxin concentrations (mg/kg) } & \multicolumn{2}{|c|}{$\log \mathrm{cfu} / \mathrm{g}$} \\
\hline & & Range & Mean & Range & Mean & Range & Mean \\
\hline Triticale & 19 & $1.28-6.45$ & $3.46^{\mathrm{a}}$ & $0,009-0,043$ & $0,024^{a}$ & $1.05-2.66$ & $1.53^{\mathrm{a}}$ \\
\hline Wheat & 35 & $1.14-7.51$ & $4.41^{\mathrm{b}}$ & $0,011-0,062$ & $0,038^{b}$ & $1.28-2.67$ & $1.75^{\mathrm{a}}$ \\
\hline Barley & 24 & $2.99-9.35$ & $6.14^{c}$ & $0,010-0,073$ & $0,036^{b}$ & $1.35-2.67$ & $2.05^{\mathrm{b}}$ \\
\hline Rye & 31 & $4.22-9.67$ & $6.73^{c}$ & $0,040-0,132$ & $0,080^{c}$ & $1.24-2.78$ & $2.36^{c}$ \\
\hline All cereals & 133 & $1.14-14.81$ & 6.15 & $0,009-0,133$ & 0,057 & $1.05-4.55$ & 2.26 \\
\hline
\end{tabular}

Identical letters in rows - no differences at the level of significance $a=0.05$

\begin{tabular}{|c|c|c|c|c|c|c|c|c|c|c|c|}
\hline \multirow{2}{*}{$\begin{array}{l}\text { B } \\
\text { Cereal }\end{array}$} & \multirow{2}{*}{$\begin{array}{c}\text { Number of } \\
\text { samples }\end{array}$} & \multicolumn{5}{|c|}{ Concentration of trichothecenes A (mg/kg) } & \multicolumn{5}{|c|}{ Concentration of trichothecenes B $(\mathrm{mg} / \mathrm{kg})$} \\
\hline & & STO & T-2 Tetraol & T-2 Triol & DAS & HT-2 & DON & Fus-X & 3-AcDON & $15-\mathrm{AcDON}$ & NIV \\
\hline Triticale & 19 & 0,001 & 0,004 & $<$ LOD & $<\mathrm{LOD}$ & $<\mathrm{LOD}$ & 0,010 & $<$ LOD & 0,002 & 0,001 & 0,005 \\
\hline Barley & 24 & 0,004 & 0,002 & 0,001 & $<\mathrm{LOD}$ & 0,001 & 0,015 & $<$ LOD & 0,002 & 0,001 & 0,009 \\
\hline Rye & 31 & 0,005 & 0,002 & 0,001 & 0,005 & 0,001 & 0,046 & 0,001 & 0,003 & 0,003 & 0,013 \\
\hline All cereals & 133 & 0,003 & 0,003 & 0,002 & 0,002 & 0,002 & 0,026 & 0,001 & 0,003 & 0,003 & 0,013 \\
\hline
\end{tabular}

\begin{tabular}{|c|c|c|c|c|c|}
\hline \multirow{2}{*}{$\begin{array}{l}\text { C } \\
\text { Cereal }\end{array}$} & \multicolumn{5}{|c|}{ Correlation coefficient } \\
\hline & $\begin{array}{l}\text { ERG/ total toxin } \\
\text { concentrations }\end{array}$ & ERG/DON & ERG/NIV & ERG/log cfu/g & $\begin{array}{l}\text { total toxin concentration/ } \\
\qquad \log \mathrm{cfu} / \mathrm{g}\end{array}$ \\
\hline Wheat & $0,6886^{* *}$ & 0,3213 & $0,5278^{* *}$ & $0,6056^{* *}$ & $0,3219^{*}$ \\
\hline Barley & $0,7135^{* *}$ & 0,1977 & $0,6547^{* *}$ & $0,6466^{* *}$ & $0,5069 * *$ \\
\hline Rye & $0,5255^{* *}$ & $0,6384^{* *}$ & $-0,3767$ & $0,7538^{* *}$ & 0,2269 \\
\hline Oat & $0,7860^{* * *}$ & 0,1298 & $0,4258^{*}$ & $0,7469^{* *}$ & $0,6888^{* *}$ \\
\hline All cereals & $0,7629 * * *$ & $0,4187^{*}$ & $0,5219^{* *}$ & $0,8559 * * *$ & $0,7586^{* * *}$ \\
\hline
\end{tabular}


HT-2, DON, Fus-X, 3-AcDON, 15-AcDON and NIV. Wheat grain ranked third in terms of the diversity of identified mycotoxins, followed by barley and triticale. Approx. $80 \%$ of all analysed samples contained group A trichothecenes: STO and T-2 Tetraol, and group B trichothecenes: DON, 3-AcDON, 15-AcDON and NIV. The other analysed mycotoxins were found in these cereals at trace amounts. Among the investigated mycotoxins the highest concentration of $0,046 \mathrm{mg} / \mathrm{kg}$ was recorded in rye grain for DON and for NIV in oat grain, amounting to $0,027 \mathrm{mg} / \mathrm{kg}$.

Based on the conducted statistical analysis, the correlation coefficients between analysed cereal characteristics were calculated. Highly significant correlations were found between ERG concentration and total toxin concentration, and between ERG concentration and $\log \mathrm{cfu} / \mathrm{g}$ for all the tested cereal species. In the case of correlations for concentrations, that of total toxin and $\log \mathrm{cfu} / \mathrm{g}$ was significant for all cereals, except for rye, although at lower confidence levels for the correlation coefficients determined for the ERG/total toxins and ERG/log cfu/g. Moreover, significant correlations were also observed between ERG and DON concentrations for triticale and rye. Significant correlations between ERG and NIV concentrations were also found in wheat, barley and oats. When considering all the cereal samples analysed in 2006, significant correlations were observed between the analysed characteristics (Tab. 2C).

In 2007, a total of 129 grain samples of 5 cereal species were tested. In that year, similar to the previous year, the contents of ERG, mycotoxins from the trichothecene group, as well as CFU numbers, were analysed (Tab. 3A). Among the investigated cereal species, oats and rye had the highest ERG concentration, amounting to 9.79 and $9.69 \mathrm{mg} / \mathrm{kg}$, respectively. In contrast, the lowest concentration of this metabolite, amounting to $1.90 \mathrm{mg} / \mathrm{kg}$, was detected in wheat grain. Total toxin concentration of $0,081 \mathrm{mg} / \mathrm{kg}$ was the highest in samples of oat grain, while the lowest, amounting to $0,018 \mathrm{mg} / \mathrm{kg}$, was found in samples of wheat grain. Similar trends as those for the level of mycotoxins and ERG were found for CFU levels, as oat grain contained the greatest counts of microscopic fungi $(3.16 \mathrm{log} \mathrm{cfu} / \mathrm{g})$, while in wheat grain it was the lowest $(1.26 \mathrm{log} \mathrm{cfu} / \mathrm{g})$. Almost $90 \%$ of the analysed samples contained DON and NIV, while approx. 65\% contained T-2 Triol (Tab. 3B). Rye grain was characterised by the highest concentrations of DON $(0,053 \mathrm{mg} / \mathrm{kg})$ and NIV $(0,026 \mathrm{mg} / \mathrm{kg})$. Wheat grain contained the lowest DON concentration, amounting to $0,013 \mathrm{mg} / \mathrm{kg}$, whereas in triticale grain the lowest NIV amounts were detected $-0,003 \mathrm{mg} / \mathrm{kg}$.

Based on the conducted statistical analysis, correlation coefficients were determined between the analysed characteristics of cereals (Tab. 3C). Highly significant correlations were observed between ERG concentration and total toxin concentration, as well as between ERG concentration and $\log \mathrm{cfu} / \mathrm{g}$ for all the tested cereals. In the case of correlations for concentrations, that of total toxins and $\log \mathrm{cfu} / \mathrm{g}$ was significant for all cereals, except rye, although

Table 3. Range and mean concentrations of total toxins and ergosterol and the value of log cfu/g (A), mean concentrations of trichothecenes $A$ and $B(B)$ in grains of 5 cereal species harvested in 2007, and correlations between analysed traits (C)

\begin{tabular}{|c|c|c|c|c|c|c|c|}
\hline \multirow{2}{*}{$\begin{array}{l}\text { A } \\
\text { Cereal }\end{array}$} & \multirow{2}{*}{$\begin{array}{c}\text { No. of } \\
\text { samples }\end{array}$} & \multicolumn{2}{|c|}{ Mean ERG concentration $(\mathrm{mg} / \mathrm{kg})$} & \multicolumn{2}{|c|}{ Mean total toxin concentrations $(\mathrm{mg} / \mathrm{kg})$} & \multicolumn{2}{|c|}{$\log c f u / g$} \\
\hline & & Range & Mean & Range & Mean & Range & Mean \\
\hline Triticale & 27 & $1.09-7.26$ & $3.13^{\mathrm{a}}$ & $0,010-0,047$ & $0,031^{\mathrm{a}}$ & $1.05-2.66$ & $1.44^{\mathrm{a}}$ \\
\hline Wheat & 31 & $0.58-4.61$ & $1.90^{\mathrm{b}}$ & $0,004-0,026$ & $0,018^{b}$ & $1.28-2.67$ & $1.26^{\mathrm{b}}$ \\
\hline Barley & 17 & $2.08-9.54$ & $7.28^{c}$ & $0,008-0,069$ & $0,052^{\mathrm{b}}$ & $1.35-2.67$ & $1.81^{\mathrm{c}}$ \\
\hline Rye & 25 & $4.55-13.00$ & $9.69^{d}$ & $0,027-0,083$ & $0,074^{c}$ & $1.24-2.78$ & $2.97^{d}$ \\
\hline All cereals & 129 & $0.58-13.00$ & 6.36 & $0,004-0,124$ & 0,047 & $1.05-4.55$ & 2.04 \\
\hline
\end{tabular}

letters in rows - no differences at the level of significance $a=0.05$

\begin{tabular}{|c|c|c|c|c|c|c|c|c|c|c|c|}
\hline \multirow{2}{*}{$\begin{array}{l}\text { B } \\
\text { Cereal }\end{array}$} & \multirow{2}{*}{$\begin{array}{c}\text { No. of } \\
\text { samples }\end{array}$} & \multicolumn{5}{|c|}{ Concentration of trichothecenes A (mg/kg) } & \multicolumn{5}{|c|}{ Concentration of trichothecenes B (mg/kg) } \\
\hline & & STO & T-2 Tetraol & T-2 Triol & DAS & HT-2 & DON & Fus-X & 3-AcDON & 15-AcDON & NIV \\
\hline Triticale & 27 & $<\mathrm{LOD}$ & 0,002 & 0,003 & 0,001 & 0,001 & 0,017 & 0,004 & 0,004 & 0,003 & 0,003 \\
\hline Wheat & 31 & 0,004 & $<\mathrm{LOD}$ & 0,001 & $<\mathrm{LOD}$ & 0,001 & 0,013 & $<\mathrm{LOD}$ & $<\mathrm{LOD}$ & 0,004 & 0,012 \\
\hline Barley & 17 & 0,004 & 0,006 & 0,004 & 0,001 & 0,001 & 0024 & 0,002 & 0,002 & 0,011 & 0,007 \\
\hline Rye & 25 & $<\mathrm{LOD}$ & 0,001 & 0,001 & 0,008 & $<\mathrm{LOD}$ & 0,053 & 0,001 & $0 ., 006$ & 0,002 & 0,026 \\
\hline All cereals & 129 & 0,004 & 0,005 & 0,003 & 0,007 & 0,002 & 0,029 & 0,001 & 0,002 & 0,007 & 0,016 \\
\hline
\end{tabular}

\begin{tabular}{|c|c|c|c|c|c|}
\hline \multirow{2}{*}{$\begin{array}{l}\text { C } \\
\text { Cereal }\end{array}$} & \multicolumn{5}{|c|}{ Correlation coefficient } \\
\hline & $\begin{array}{l}\text { ERG/total toxin } \\
\text { concentrations }\end{array}$ & ERG/DON & ERG/NIV & ERG/log cfu/g & $\begin{array}{l}\text { Total toxin concentrations/ } \\
\qquad \log \mathrm{cfu} / \mathrm{g}\end{array}$ \\
\hline Wheat & $0,7032^{* *}$ & $0,4867^{*}$ & $0,4957^{*}$ & $0,7215^{* *}$ & $0,4284^{*}$ \\
\hline Barley & $0,6489 * *$ & $0,3652^{*}$ & $0,7012^{* *}$ & $0,7019 * *$ & $0,5654^{* *}$ \\
\hline Rye & $0,5527^{* *}$ & $0,7008^{* *}$ & $-0,4347$ & $0,8326^{* * *}$ & 0,3661 \\
\hline Oat & $0,8106^{* * *}$ & $0,4204^{*}$ & 0,3471 & $0,7558^{* * *}$ & $0,7205^{* *}$ \\
\hline All cereals & $0,7248^{* * *}$ & $0,5681^{* *}$ & $0,6022^{* *}$ & $0,8726^{* * *}$ & $0,7895^{* * *}$ \\
\hline
\end{tabular}


Table 4. Range and mean concentrations of total toxins and ergosterol, and the value of log cfu/g (A), mean concentrations of trichothecenes $A$ and $B(B)$ in grains of 5 cereal species harvested in 2008, and correlations between analysed traits (C)

\begin{tabular}{|c|c|c|c|c|c|c|c|}
\hline \multirow{2}{*}{$\begin{array}{l}\text { A } \\
\text { Cereal }\end{array}$} & \multirow{2}{*}{$\begin{array}{c}\text { No. of } \\
\text { samples }\end{array}$} & \multicolumn{2}{|c|}{ ERG concentration (mg/kg) } & \multicolumn{2}{|c|}{ Mean total toxin concentrations (mg/kg) } & \multicolumn{2}{|c|}{$\log c f u / g$} \\
\hline & & Range & Mean & Range & Mean & Range & Mean \\
\hline Triticale & 19 & $1.10-5.40$ & $2.80^{\mathrm{a}}$ & $0,006-0,041$ & $0,033^{\mathrm{a}}$ & $1.22-1.84$ & $1.52^{\mathrm{a}}$ \\
\hline Wheat & 35 & $0.47-5.21$ & $2.01^{\mathrm{a}}$ & $0,012-0,033$ & $0,028^{\mathrm{a}}$ & $1.13-2.10$ & $1.30^{\mathrm{b}}$ \\
\hline Barley & 19 & $4.95-9.77$ & $7.33^{\mathrm{b}}$ & $0,023-0,091$ & $0,083^{b}$ & $1.68-2.59$ & $2.11^{c}$ \\
\hline Rye & 25 & $9.05-13.96$ & $11.54^{c}$ & $0,021-0,151$ & $0,117^{c}$ & $2.47-3.56$ & $3.42^{\mathrm{d}}$ \\
\hline All cereals & 116 & $0.47-15.68$ & 7.00 & $0,006-0,151$ & 0,061 & $1.13-3.83$ & 2.12 \\
\hline
\end{tabular}

Identical letters in rows - no differences at the level of significance $\mathrm{a}=0.05$

\begin{tabular}{|c|c|c|c|c|c|c|c|c|c|c|c|}
\hline \multirow{2}{*}{$\begin{array}{l}\text { B } \\
\text { Cereal }\end{array}$} & \multirow{2}{*}{$\begin{array}{c}\text { No. of } \\
\text { samples }\end{array}$} & \multicolumn{5}{|c|}{ Concentration of trichothecenes $\mathrm{A}(\mathrm{mg} / \mathrm{kg})$} & \multicolumn{5}{|c|}{ Concentration of trichothecenes B $(\mathrm{mg} / \mathrm{kg})$} \\
\hline & & STO & T-2 Tetraol & T-2 Triol & DAS & HT-2 & DON & Fus-X & 3-AcDON & $15-A c D O N$ & NIV \\
\hline Triticale & 19 & 0.002 & 0.001 & 0.001 & 0.002 & $<\mathrm{LOD}$ & 0.021 & 0.003 & 0.001 & 0.004 & 0.001 \\
\hline Wheat & 35 & 0.006 & 0.003 & $<\mathrm{LOD}$ & 0.001 & 0.007 & 0.025 & $<\mathrm{LOD}$ & 0.003 & 0.001 & 0.009 \\
\hline Barley & 19 & $<\mathrm{LOD}$ & 0.004 & 0.003 & 0.002 & 0.002 & 0.041 & 0.001 & 0.001 & 0.004 & 0.001 \\
\hline Rye & 25 & 0.001 & $<\mathrm{LOD}$ & 0.007 & 0.007 & 0.001 & 0.038 & 0.003 & 0.005 & 0.008 & 0.038 \\
\hline All cereals & 116 & 0.008 & 0.004 & 0.004 & 0.006 & 0.005 & 0.015 & 0.002 & 0.003 & 0.004 & 0.011 \\
\hline
\end{tabular}

\begin{tabular}{lcccc}
\hline Cereal & \multicolumn{3}{c}{ Correlation coefficient } \\
\cline { 2 - 5 } & $\begin{array}{c}\text { ERG/ total toxin } \\
\text { concentrations }\end{array}$ & ERG/DON & ERG/NIV & $\begin{array}{c}\text { Total toxin concentrations/ } \\
\text { log cfu/g }\end{array}$ \\
\hline Triticale & $0.6120^{* *}$ & $0.6621^{* *}$ & 0.3022 & $0.6732^{* *}$ \\
\hline Wheat & $0.5419^{* *}$ & 0.3183 & 0.3631 & $0.6016^{* *}$ \\
\hline Barley & $0.6720^{* *}$ & $0.4021^{*}$ & $0.4228^{*}$ & $0.5271^{* *}$ \\
\hline Rye & $0.5277^{* *}$ & $0.6284^{* *}$ & 0.3712 & $0.6922^{* *}$ \\
\hline Oat & $0.7202^{* *}$ & $0.4622^{*}$ & $0.4333^{*}$ & $0.5852^{* *}$ \\
\hline All cereals & $0.5831^{* *}$ & $0.4101^{*}$ & $0.5284^{* *}$ & $0.6241^{* *}$ \\
\hline
\end{tabular}

at lower confidence levels than the correlation coefficients for ERG/total toxins and ERG/log cfu/g. For all analysed cereal species, significant correlations were also observed between ERG and DON concentrations, while significant correlations were found between ERG and NIV concentrations in wheat and barley.

In 2008, a total of 116 grain samples of 5 cereal species were tested. In that year, similar to the previous years, analyses were conducted on the contents of ERG, mycotoxins from the trichothecene group, as well as the number of CFU (Tab. 4A). Among the analysed cereal species, rye and oats were characterised by the highest ERG concentration, amounting to 11.54 and $11.32 \mathrm{mg} / \mathrm{kg}$. In contrast, the lowest concentration of this metabolite, amounting to $2.01 \mathrm{mg} / \mathrm{kg}$, was recorded in wheat grain. Total toxin concentration was the highest $(0.121 \mathrm{mg} / \mathrm{kg})$ in samples of oat grain, while the lowest level, at $0,028 \mathrm{mg} / \mathrm{kg}$, was found in samples of wheat grain. A similar trend to that observed for the levels of mycotoxins and ERG was found for CFU, i.e. oat grain contained the greatest amounts of microscopic fungi (3.20 log cfu/g), rye grain contained a similar count of moulds amounting to $2.42 \mathrm{log} \mathrm{cfu} / \mathrm{g}$, while in wheat grain it was the lowest (1.30 log cfu/g). Over 95\% of the analysed samples contained DON and NIV, while DAS was detected in approx. $70 \%$ samples. Barley grain had the highest DON concentration $(0,041 \mathrm{mg} / \mathrm{kg})$, while the highest NIV concentration was found in rye grain $(0.037 \mathrm{mg} / \mathrm{kg})$. Oat grain contained the lowest DON concentration, amounting to $0.019 \mathrm{mg} / \mathrm{kg}$, while triticale grain contained the lowest amount of NIV at $0.001 \mathrm{mg} / \mathrm{kg}$ (Tab. 4B).

Based on the conducted statistical analysis, correlation coefficients were determined between analysed cereal characteristics. Highly significant correlations were observed between ERG concentration and total toxin concentration, ERG concentration and $\log \mathrm{cfu} / \mathrm{g}$, and between total toxin concentration and $\log \mathrm{cfu} / \mathrm{g}$ for all tested cereals. In all tested cereal species, except for wheat, a significant correlation was found between ERG and DON concentrations. Significant correlations between ERG and NIV concentrations were also found in the case of barley and oats (Tab. 4C).

\section{DISCUSSION}

During 2006-2008, the tested cereal species had similar low concentrations, both for the tested fungal metabolites and the level of microscopic fungi. However, statistical analyses showed a significant variation between the tested grains. Oat and rye grain contained the highest amounts of ERG, total toxins and CFU. In turn, the lowest values of the investigated parameters were recorded for wheat and triticale grain. Based on the recorded results, it may be stated that the amount of mycobiota in naturally infested grain varies for each tested cereal species. Thus, the results need to be compared with current literature data presented on the subject, since presently there are no binding legal regulations in this 
respect. Initially, ERG concentration of $3 \mathrm{mg} / \mathrm{kg}[6]$ was assumed as the safe content of mycobiota in healthy grain. On the other hand, based on their extensive studies, Schnörer and Johnson (1992) [7] proposed the range of concentrations for this metabolite at $1-9 \mathrm{mg} / \mathrm{kg}$ as the boundary value for grain for human consumption. The determined mean ERG concentrations for all the tested cereals did not exceed the boundary value indicated in literature. However, between the tested cereal species differences were found in the mean ERG concentration. When investigating individual cereals it was found that in oat and rye grain the recorded concentrations exceeded $9 \mathrm{mg} / \mathrm{kg}$. Similar differences between contents of mycobiota for individual cereals were observed by Schnörer and Johnson (1992) [7] who, for wheat, recorded the range of ERG concentrations from $0.32-4.40 \mathrm{mg} / \mathrm{kg}$, for triticale the mean concentration of this metabolite was $5.20 \mathrm{mg} / \mathrm{kg}$, whereas for rye it was $5.10 \mathrm{mg} / \mathrm{kg}$. Perkowski et al. (2008) [7] recorded ERG concentrations in grain samples of wheat, barley and oats. The highest concentration of this metabolite, i.e. $8.69 \mathrm{mg} / \mathrm{kg}$, was found in oat grain, it was lower in barley grain at $2.39 \mathrm{mg} / \mathrm{kg}$, and the lowest in wheat grain at $1.26 \mathrm{mg} / \mathrm{kg}$. Stuper et al. (2008) [8] also observed that among the analysed cereals wheat was characterised by the lowest mean ERG concentration of $2.87 \mathrm{mg} / \mathrm{kg}$, while the other tested cereals contained greater amounts of this metabolite in the following order: triticale at $4.67 \mathrm{mg} / \mathrm{kg}$, rye $9.97 \mathrm{mg} / \mathrm{kg}$, barley $11.38 \mathrm{mg} / \mathrm{kg}$ and oats at $14.98 \mathrm{mg} / \mathrm{kg}$. Similar results concerning ERG concentrations in wheat grain were reported by Seitz et al. (1977) [9] and Müller and Lehn (1988) [10]. In barley grain in 1983-1985, Müller and Lehn (1988) [10] observed no significant differences between ERG contents depending on the year of analysis, with ERG concentrations ranging from 2.03-3.06 mg/kg. Miedaner and Perkowski (1996) [11] in artificially inoculated samples strongly infested with Fusarium culmorum observed a great variation in ERG concentrations in rye grain tested in 1992-1993, while the mean concentration of this metabolite in relation to naturally infested samples was markedly higher, amounting to $85 \mathrm{mg} / \mathrm{kg}$ in 1992, while it was $66 \mathrm{mg} / \mathrm{kg}$ in 1993.

Contents of microscopic fungi measured by colony forming units was low in all cereals, ranging from $10^{1} \mathrm{cfu} / \mathrm{g}$ to over $10^{3} \mathrm{cfu} / \mathrm{g}$. The greatest number of CFU was recorded in barley grain, while mycological contamination in cereals at $10^{3}-$ $10^{4} \mathrm{cfu} / \mathrm{g}$ is considered to be natural infestation [7]. Results comparable to those presented in this study in the case of CFU levels in barley grain were reported by GawrysiakWitulska et al. (2008) [12]. In grain immediately after harvest they recorded approx. $10^{4} \mathrm{cfu} / \mathrm{g}$. In turn, Baliukoniene et al. (2003) [13] reported higher CFU levels in tested barley grain (4.3 log cfu/g) and wheat grain (4.2 log cfu/g) in samples from family farms in Lithuania. Neagu and Tofan (2008) [14] analysed samples of wheat, oat and barley from central Romania. They recorded low contents of microscopic fungi amounting to $12 \mathrm{cfu} / \mathrm{g}$ for wheat, $4 \mathrm{cfu} / \mathrm{g}$ for barley and $6 \mathrm{cfu} / \mathrm{g}$ for oats, respectively. Krysińska-Traczyk et al. (2001) [15] reported that in wheat grain harvested in eastern Poland, contamination with microscopic fungi ranged from 0 $227.5 \times 10^{3} \mathrm{cfu} / \mathrm{g}$.

Apart from the contents of mycobiota in cereal samples, analyses were also conducted on the concentrations of mycotoxins. The level of group A and B trichothecenes during the 3 years of the study remained low, while DON concentration did not exceed $1,250 \mu \mathrm{g} / \mathrm{kg}$, considered to be safe in grain for human consumption, in any sample. In the course of this study, in 2007 the admissible DON concentration in cereals and bakery goods was exceeded in 7 cases, while 4 such cases were reported in 2008 [16]. Unfortunately, there are no data for the year 2006, because it was only since 2006 on the authority of the European Commission (Regulation No. 1881/2006 of 19.12.2006, Official Journal of EU L 364/5) that DON concentration in cereals and cereal products started to be legally regulated. Detailed information on the contents of trichothecenes in cereal grain in Europe is provided by numerous literature reports. Keblys et al. (2000) [17] analysed DON contents in samples of naturally infested barley, rye and wheat grain. In wheat samples, the concentration of DON was below the level of detection, while rye samples contained a mean DON concentration of $20 \mu \mathrm{g} / \mathrm{kg}$, and in barley grain the mean DON concentration was $101 \mu \mathrm{g} / \mathrm{kg}$. Similar mean results for DON concentrations were recorded by Garaleviciene et al. (2002) [18] for wheat, barley and oats, amounting to 22, 138 and $112 \mu \mathrm{g} / \mathrm{kg}$, respectively. Significant differences between cereal species in terms of the contents of DON and other group B trichothecenes were also observed by Mankevičiene et al. (2007) [19]. In their study, those authors detected the highest DON concentration in samples of rye grain, amounting to $691 \mu \mathrm{g} / \mathrm{kg}$, a lower concentration was found in barley grain at $198 \mu \mathrm{g} / \mathrm{kg}$, whereas it was the lowest in triticale grain at $168 \mu \mathrm{g} / \mathrm{kg}$ and oats at $122 \mu \mathrm{g} / \mathrm{kg}$.

\section{CONCLUSIONS}

The results presented in this study for the 3-year analyses of contents of mycobiota and trichothecenes in grain of 5 cereal species indicate a low level of contamination with microscopic fungi and toxins in cereals for human consumption in Poland. The statistically slight differences between contents of analysed metabolites in the years of the study do not confirm observations on the significance of the effect of weather conditions on the development of, or the production of mycotoxins, but this pertains to treatments exhibiting no strong infestation. Highly significant correlations between the contents of trichothecenes and ERG concentration (higher than in the case of the correlation between total toxin concentration and $\log \mathrm{cfu} / \mathrm{g}$ ) indicate that the level of this metabolite is inseparably connected with the contents of mycotoxins in grain.

\section{REFERENCES}

1. Richard JL. Some major mycotoxins and their mycotoxicoses-an overview. Int J Food Microbiol. 2007; 119: 3-10.

2. Perkowski J, Buśko M, Stuper K, Kostecki M, Matysiak A, SzwajkowskaMichałek L. Concentration of ergosterol in small-grained naturally contaminated and inoculated cereals, Biologia 2008; 63(4): 542-547.

3. Sobrova P, Adam V, Vasatkova A, Beklova M, Zeman L, Kizek R. Deoxynivalenol and its toxicity. Interdisc Toxicol. 2010; 3(3): 94-99.

4. Perkowski J, Wiwart M, Stuper K, Buśko M, Matysiak A, Suchowilska E. Concentration of fungal biomass and trichothecenes in different parts of einkorn. Ann Agric Environ Med. 2011; 18: 111-119.

5. Stuper-Szablewska K, Perkowski J. Contamination of wheat grain with microscopic fungi and their metabolites in Poland in 2006-2009. Ann Agric Environ Med. 2014; 21(3): 598-603.

6. Maupetit P, Gatel F, Cahagnier B, Botorel G, Charlier M, Collet B, Dauvillier P, Laffiteau J, Roux G. Quantitative estimation of fungal infestation of feedstuffs by determining ergosterol content, 44Th 
Annual meeting of EAAP Aarhus, Denmark, 16-19 August 1993, Commission of animal nutrition, 16, 20.

7. Schnürer J, Jonsson A. Ergosterol levels and mould colony forming units in Swedish grain of food and feed grade. Acta Agric Scan. 1992; 42: $240-245$

8. Stuper K, Buśko M, Perkowski J. Rozwój chemicznych metod oznaczania zawartości mikroflory grzybowej w produktach zbożowych. ABiD. 2008; 4: 68-74 (in Polish).

9. Seitz LM, Mohr HE, Burroughs R, Sauer DB. Ergosterol as an indicator of fungal invasion in grains. Cereal Chem. 1977; 54: 1207-1217.

10. Müller HM, Lehn C. Ergosterin als Mass für das Pilzwachstum in Futtermitteln. 1. Mitteilung. Ergosteringehalt von Getride. Arch Anim Nut. 1988; 38: 227-240.

11. Miedaner T, Perkowski J. Correlations among Fusarium culmorum head blight resistance, fungal colonization and mycotoxin contens in winter rye. Plant Breed. 1996; 115: 347-351.

12. Gawrysiak-Witulska M, Wawrzyniak J, Ryniecki A, Perkowski J. Relationship of ergosterol content and fungal contamination and assessment of technological quality of malting barley preserved in a metal silo using the near-ambient method. J Stored Prod Res. 2008; 44: 360-365.
13. Baliukoniene V, Bakutis B, Stankevicius H. Mycological and mycotoxicological evaluation of grain. Ann Agric Environ Med. 2003; 10: 223-227.

14. Neagu C, Tofan C. Cereal contamination with toxinogenic moulds. J Agroaliment Proces Tech. 2008; 14: 237-24.

15. Krysińska-Traczyk E, Kiecana I, Perkowski J, Dutkiewicz J. Levels of fungi and mycotoxins in samples of grain and grain dust collected on farms in eastern Poland. Ann Agric Environ Med. 2001; 8: 269-274.

16. Schothorst K, van Egmond D. 2004. Report EC SCOOP TASK 3.2.10. Collection of occurrence data of Fusarium toxins in food and assessment of dietary intake by the population of EU Member States. [http://ec.europa. eu/food/fs/scoop/task3210.pdf].

17. Keblys M, Flyen A, Langseth W. Changes in grain production, mechanisms for sale of grain and possible effects on grain quality in Lithuania in the period 1990-1999. Acta Agric Scan. 2000; 50: 97-101.

18. Garaleviciene D, Pettersson H, Agnedal M. Occurrence of trichothecenes, zearalenone and ochratoxin A in cereals and mixed feed from central Lithuania. Mycotoxin Res. 2002; 18: 77-89.

19. Mankevičienè A, Butkute B, Dabkevičius Z, Supronienè S. Fusarium mycotoxins in Lithuanian cereals from the 2004-2005 harvests. Ann Agric Environ Med. 2007; 14: 103-107. 